\title{
THE EFFECT OF CIRCULATING FAN AND NATURAL VENTILATION ON THE THERMAL COMFORT PERFORMANCE IN A BUILDING IN SOUTHEAST SULAWESI
}

\author{
Aditya Rachman', Aspin ${ }^{2}$, Siti Belinda ${ }^{2}$ \\ ${ }^{1}$ Staf Pengajar Program Studi Teknik Mesin Fakultas Teknik Universitas Halu Oleo, Kendari \\ Kampus Hijau Bumi Tridarma Andounohu Kendari 93232 \\ ${ }^{2}$ Staf Pengajar Program Studi Teknik Arsitekur Fakultas Teknik Universitas Halu Oleo, Kendari \\ Kampus Hijau Bumi Tridarma Andounohu Kendari 93232 \\ E-mail: aditya_rchmn@yahoo.com
}

\begin{abstract}
The unbalance on the supply and demand on the energy has an impact on the escalating energy price and potentially impedes the development. One of the power demands comes from the energy utilization in the building sector, in which the cooling system is among them. The application of the air conditioning based on the refrigerator system is obviously consuming much energy in the building. Thus reducing the role of this power consumed cooling system is so imperative. To apply the circulating fan or to employ the natural ventilation are among the alternative approaches to make a building cooler, without much consuming energy. The aim of this study is to investigate the effect the circulating fan and the natural ventilation, on the temperature and the humidity in a building in Southeast Sulawesi, a region with its high daily solar radiation. It conducts an experiment on a building model incorporated with the ventilation and the circulating fan. The result shows that by incorporating these alternative cooling devices, the temperatures in the building can be lower than that of a closed building (no fan and no ventilation). The magnitude in the decreasing on the temperature for the building with circulating fan is higher than that of the ventilation. Another result on the investigation shows that the relative humidity in the building with the circulating fan or the ventilation is relatively higher than that of the closed building.
\end{abstract}

Keywords : circulating fan, natural ventilation, temperature, humidity, building

\begin{abstract}
Abstrak
Pengaruh fan sirkulasi dan ventilasi alami terhadap kinerja kenyamanan termal bangunan di Sulawesi Tenggara. Ketidakseimbangan pasokan dan permintaan energi memiliki dampak pada harga energi meningkat dan dapat berpotensi menghambat pembangunan. Salah satu sumber permintaan energi berasal dari penggunaan energi di sektor bangunan, di mana sistem pendingin adalah salah satunya. Penerapan AC berbasis sistem refrigasi telah banyak mengkonsumsi penggunaan energi dalam bangunan, sehingga usaha untuk mengurangi peran sistem pendinginan ruangan ini menjadi sangat penting. Penerapan fan sirkulasi atau ventilasi alami adalah merupakan metode alternatif untuk mendinginkan bangunan, tanpa banyak mengkonsumsi energi. Tujuan dari penelitian ini adalah untuk menyelidiki pengaruh fan sirkulasi dan ventilasi alami, pada suhu dan kelembaban di sebuah bangunan di Sulawesi Tenggara, sebuah daerah dengan radiasi matahari harian yang tinggi. Metode yang digunakan dalam penelitian ini adalah kajian eksperimen pada sebuah model bangunan yang dilengkapi dengan ventilasi dan fan sirkulasi. Hasil penelitian menunjukkan bahwa dengan menggunakan perangkat pendingin alternatif ini, suhu di dalam bangunan bisa lebih rendah dari bangunan tertutup (tanpa fan sirkulasi dan ventilasi ). Besarnya penurunan suhu untuk bangunan dengan fan sirkulasi lebih tinggi daripada ventilasi. Hasil lain dalam penelitian ini menunjukan bahwa kelembaban relatif di bangunan dengan fan sirkulasi atau ventilasi relatif lebih tinggi dari bangunan tertutup.
\end{abstract}

Kata Kunci: fan sirkulasi, ventilasi alami, suhu, kelembaban, bangunan 


\section{Introduction}

Energy is very important for human being. The development will pose a considerable challenge when the energy is not present. Nowadays, the scarcity of the energy supply, coupled with the increasing demand on the energy raises people awareness to make efficiency in the power use.

The current energy use is also posed by the constraint on the environmental issues. It is believed that one of the causes for the global warming is the increase in $\mathrm{CO}_{2}$ emissions in atmosphere, where the energy use is responsible for it. This condition is believed to make the earth getting warmer and is predicted to affect the balance of life in the future, the polar ice caps melt, the sea levels rise, until the creation of a series of wind storms and disasters (IPCC, 2014).

One of the options to make the energy efficiency is to reduce the energy use in buildings. About $40 \%$ of global energy is utilized by buildings. It has contributed in emitting approximately one-third of the global GHG (Greenhouse Gas) emissions (UNEP, 2014). One of the major energies used in the building comes from air cooling in order to derive the human thermal comfort. It is believed that by employing the alternative less-power cooling system, such as natural ventilation, instead of the conventional power consumed refrigerator cooling system, it can potentially reduce the building energy consumption. The ventilation possibly makes the exchange of air from outside to inside the building, by natural air movement, reducing the inner air temperature.

But in a lot of practice, in employing the natural ventilation system, it often feels inadequate to circulate air, possibly still making uncomfortable for the people in the building. A study in Voss et al (2013) finds that the passive cooling based on ventilation is insufficient under high thermal stress due to insufficient heat retraction by free or forced ventilation. Air change rates are practically limited and temperature differences, in which the factors driving the air movement, are mostly small.

Thus, it is essential to drive more air changes but still utilizing the less power consumption devices, where it can be, one of them, rolled by circulating fan. The ASHRAE standard (Std-55, 2004) indicates that the acceptable indoor air speed in warm climates should range from 0.2 to $1.50 \mathrm{~m} / \mathrm{s}$ $(0.2 \mathrm{~m} / \mathrm{s}$ for air conditioned environments $)$.

For Southeast Sulawesi, maintaining the thermal comfort is not an easy approach. The thermal environment condition must be carefully considered as in fact, the position of this region around equator line should require more heat remover in a building to gain the thermal convenience for the occupants. A data in NASA (2014) shows that the daily solar radiation in this region is around $5 \mathrm{KWH} / \mathrm{m}^{2}$.

As the conventional air conditioning obviously requires high power consumption, the application of the less power consumed ventilation and fan can be the alternative ways to obtain the desirable thermal performance in this region. Many references actually discuss the influences on the fan and the ventilation on the thermal comfort performance in the environment. However, the references conforming to the local climatic condition of Southeast Sulawesi, to discuss this matter are still rarely found. The purpose of this study is to investigate the effect circulating fan and natural ventilation, on the thermal comfort performance in a building in Southeast Sulawesi.

\section{Literature Studies}

\section{Natural ventilation}

Natural ventilation is the process of supplying and removing air through an indoor space without using mechanical systems. The pressure or temperature difference makes the flow of external air to an indoor space. There are two types of natural ventilation occurring in buildings: wind driven ventilation and buoyancy-driven ventilation. In the wind driven ventilation, the air flow is caused by the wind, while, in the buoyancy-driven ventilation, it is caused by the directional buoyancy force as a results of the temperature differences between the interior and exterior (Linden, 1999).

There are many works which study the relation of the natural ventilation to the thermal comfort performance. Liping et al (2007) investigates the application of the natural ventilation on the indoor thermal comfort of residential buildings. It employs climatic data analyses, such as temperatures, wind speeds and wind directions. It is found that by applying the ventilation, it obtains 
a large number of hours annually of a thermally comfortable indoor environment for the buildings.

A study in Salas et al (2014) evaluates the flow rate through the window using a windexchanger (a small structure placed on the roof of a building with the aim of increasing the wind driven ventilation). It uses an experiment with scaled models in an open water channel. The result shows that the windexchangers can improve the flow rate more than four times.

A study in (Oropeza et al, 2014) shows the potential of natural ventilation as a passive cooling for residential sector in warm countries using Mexico as a case study. It employs a simplified ventilation model, thermal-airflow simulations of many common cases of dwellings based on the combination of specific features of the building design, occupancy and climate conditions. The result show a saving potential of more than $50 \%$ of the air-conditioning demand in Mexico in 2008.

\section{Circulating fan}

Mechanical ventilation can provide continuously moving air that will keep home cooler, day and night, with circulating fans, whole-house fans, and evaporative coolers (National Renewable Energy Laboratory (NREL), 2001). The mechanical ventilation systems are capable of providing a controlled rate of air exchange and may respond to the varying needs of occupants and pollutant loads, irrespective of climate vagaries. In some regions in Canada and Scandinavia, mechanical ventilated systems are being incorporated into virtually all new apartment building construction and are also being included in many building renovation programs (Diamond et al, 2010).

Ceiling fans, when properly used, may reduce both heating and air-conditioning costs. The power consumption of an average ceiling fan at high speed is about 75 watts, while that of the air conditioner, it may consume more than 2 Kilo-watt of electricity (West, 2013). Another type of fan, a window fan, is suitable for windows facing the prevailing wind or away from it to provide crossventilation. The window fans augment any breeze or create a breeze when the air is still (NREL, 2001).

\section{Thermal Comfort}

Thermal comfort is the condition of mind that expresses satisfaction with the thermal environment and is assessed by subjective evaluation (ANSI/ASHRAE Standard 55). Maintaining this standard of thermal comfort for occupants of buildings or other enclosures is one of the important goals of the HVAC (Heating, Ventilation, and Air Conditioning) design engineers (ASHRAE, 2013). In ASHRAE Standard 55-2013, for thermal comfort purposes for the human occupancy, temperature could range between approximately 19.5 and $27.7{ }^{\circ} \mathrm{C}$ and that of the relative humidity to be controlled less than $65 \%$.

\section{Air movement for thermal comfort performance}

Instead of the thermal properties, many studies also relate the thermal comfort performance to the air movement. A study in Candido et al (2010) shows at operative temperatures above $24{ }^{\circ} \mathrm{C}$, it is preferred for building occupants to obtain the mean air speeds up to $1 \mathrm{~m} / \mathrm{s}$. A study in Cheng [2006] reports that, when the airspeed is increased to about $1.5 \mathrm{~m} / \mathrm{s}$, the upper comfort temperature limit further moved up by $1.5{ }^{\circ} \mathrm{C}$ and the predicted comfort range far above the maximum outdoor air temperature. However, a study in Heidari (2008) finds the increased air movement above $37^{\circ} \mathrm{C}$ to be counterproductive, resulting in heating sensation.

A report in Brager et al (2004) from a field study of office buildings shows that the peoples' preferences for higher air movement have increased with increase in thermal sensation. A study in Feriadi et al (2004) shows that people consciously recognize air movement as having a direct impact on their thermal comfort, and that their air movement preferences are for a change of air movement as needed to return to comfort quickly, especially in warm humid climates.

\section{Air properties}

Following section presents some air properties. Firstly, it is dry-bulb temperature. It is indicated by a thermometer exposed to the air in a place sheltered from direct solar radiation. The term drybulb is customarily added to temperature to distinguish it from wet-bulb and dew-point temperature. Secondly, it is wet-bulb temperature. The thermodynamic wet-bulb temperature is 


\section{DINAMIKA Jurnal Ilmiah Teknik Mesin}

a thermodynamic property of a mixture of air and water vapor. The value indicated by a wet-bulb thermometer often provides an adequate approximation of the thermodynamic wet-bulb temperature. Third, it is relative humidity $(\mathrm{RH})$. It is the ratio of the amount of water vapor in the air to the amount of water vapor that the air could hold at the specific temperature and pressure. At high $\mathrm{RH}$, the air has close to the maximum water vapor that it can hold, so evaporation decreases. At low RH, air is very dry (Balaras, 2007).

\section{Psychometrics}

Psychometrics is a term used to describe the field of engineering concerned with the determination of physical and thermodynamic properties of gasvapor mixtures. In a Psychometric chart, it is possible to determine the properties of air, when, at least, two another data of the air properties are known.

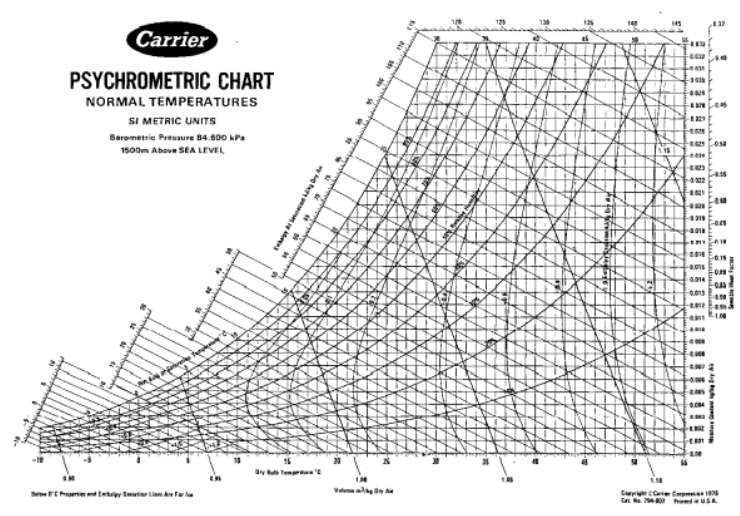

Figure 1. Psychometric Chart (Source: Carrier, 1974)

\section{Southeast Sulawesi and its climatic condition}

Southeast Sulawesi has two seasons, dry and rainy seasons. The dry season occurs from June to September, and the rainy season occurs from December to March. The transitional periods between the two seasons are April to May and October to November (BPS Southeast Sulawesi, 2012).

The air temperature is influenced by geographical position and the altitude above the sea level. Southeast Sulawesi which is located on the equator with an altitude below 1000 meters has a tropical climate. In 2009, the range of average maximum temperature is around $30^{\circ} \mathrm{C}-35^{\circ} \mathrm{C}$, and the average minimum temperature is around $22^{\circ} \mathrm{C}-25^{\circ} \mathrm{C}$, with the relative humidity around $50 \%-82 \%$ (BPS Southeast Sulawesi , 2012).

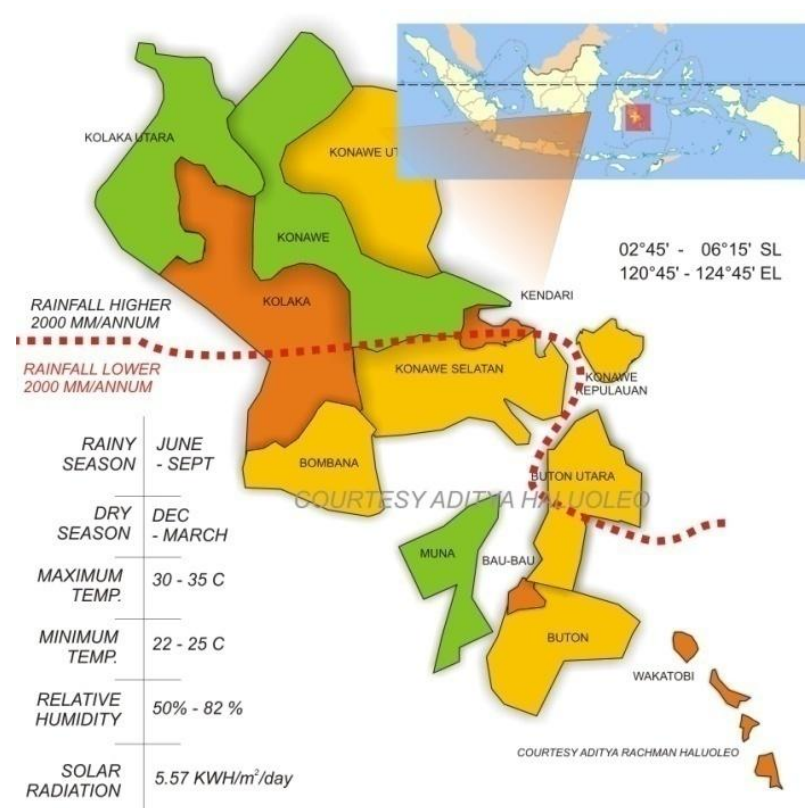

Figure 2. Southeast Sulawesi: Map and Climate (Source: BPS Southeast Sulawesi, 2012)

\section{Methodology}

The methodology of this study is an experiment of a model of small scale building. This study proposes the model in the size of $3 \times 4 \times 2 \mathrm{~m}^{3}$ (see Figure 3). The building is incorporated with ventilation and exhaust fan.

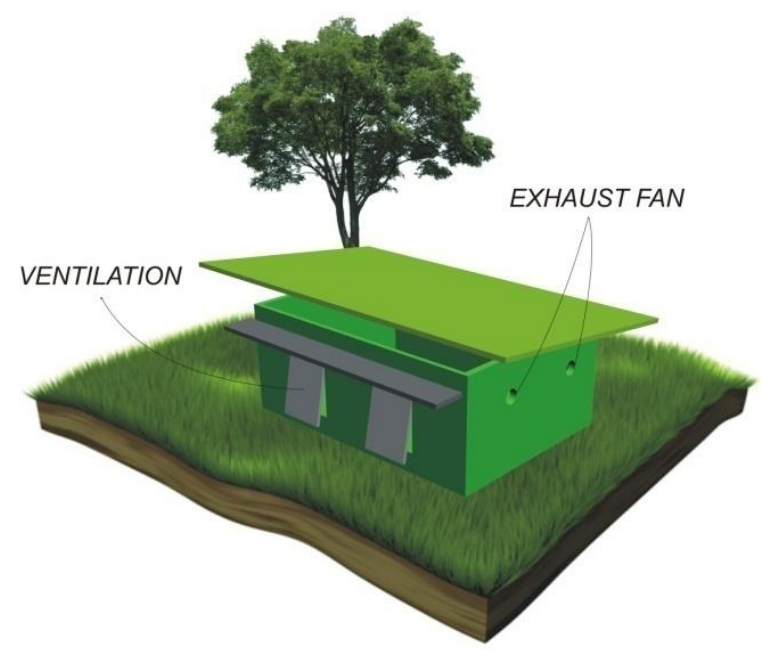

Figure 3. The model of building with ventilation and circulating fan 


\section{DINAMIKA Jurnal Ilmiah Teknik Mesin}

Into the model, it applies three configurations. The first configuration is to apply the circulating fan. In this configuration, the fan operates, and the ventilation is to let open. The second configuration is to apply ventilation. In this configuration, the ventilation is open, and the fan stops operating (but it's opening still open). This let the air flow from inside to outside on the building. The third configuration is to make the building totally closed. In this configuration, both ventilation and fan stop operating.

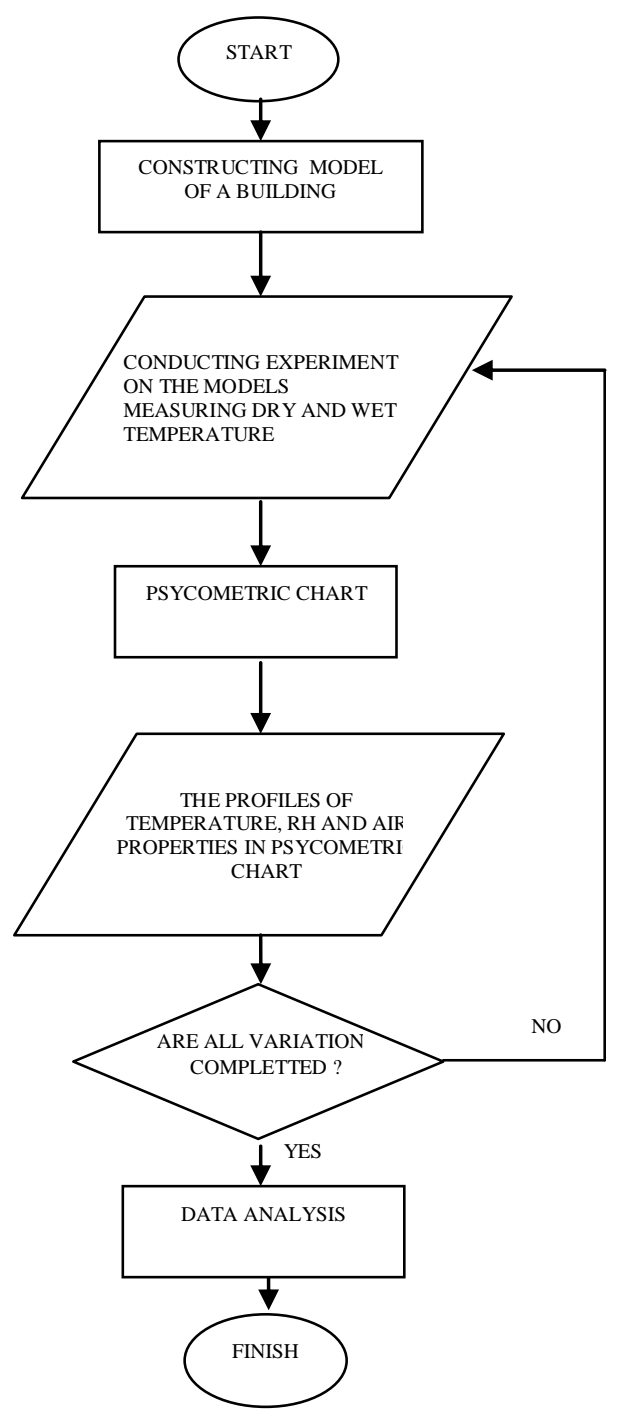

Figure 4. The flowchart diagram of the experiment

In the middle of the building, thermometers to measure the dry and wet temperatures are placed. The data of the dry and wet temperatures are utilized to predict the amount of the humidity in the building, with the assistance of the psychometric chart. It collects the data for three months, during September - November 2013. The data of the dry and wet temperatures and the outside temperatures, and the relative humidity then are also being averaged, to make easy in presenting the results. The detail of the experiment stages is figured in following flowchart.

\section{Result and Discussion}

Figure 5 shows the dry and wet bulb temperatures at inside the building and the outside temperatures in the case of applying circulating the fan. The pattern for the three temperatures is similar. In the morning, they are low, then as the sun above the head (at noon), the temperature increases. It continues to 13.00 , before decreasing at the afternoon.

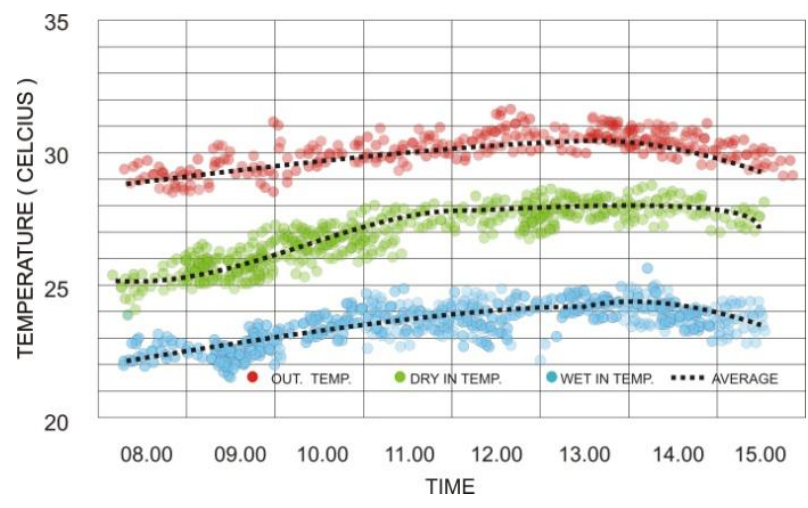

Figure 5. The temperature profile in the case of applying circulating fan

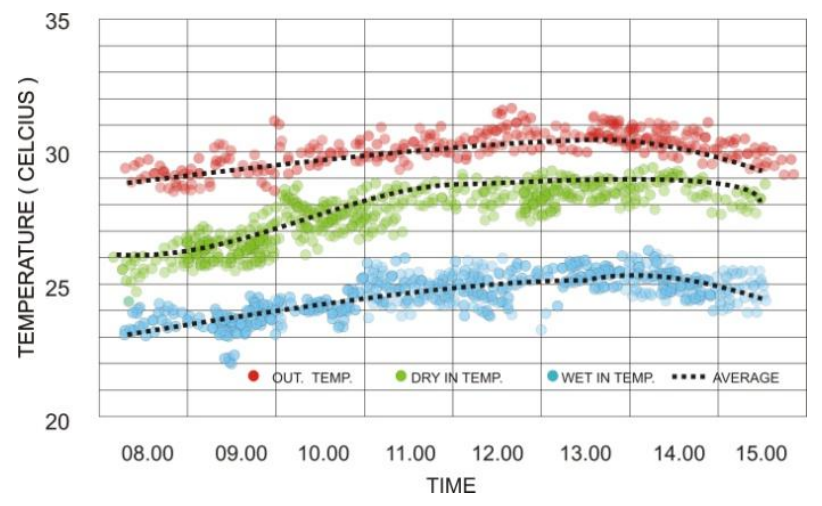

Figure 6. The temperature profile in the case of applying ventilation 
At their average values, at 08.00 in the morning, the inlet dry temperature is around $25.5^{\circ} \mathrm{C}$, while that at outside is around $28.8^{\circ} \mathrm{C}$. At 12.00 noon, the inlet dry temperature is around $28.2^{\circ} \mathrm{C}$, while that at the outside, it is around $30,5^{\circ} \mathrm{C}$. The average maximum dry temperature at the inside of the building is around $28.2{ }^{\circ} \mathrm{C}$ at 13.00 .

Figure 6 shows the dry and wet bulb temperatures in the building and the temperatures outside in the case of applying the ventilation. The pattern for the three temperatures is similar to the previous case. At 08.00 in the morning, the average inlet dry temperature is around $26,2{ }^{\circ} \mathrm{C}$, then increasing to almost $29{ }^{\circ} \mathrm{C}$ at 12.00 noon. The average maximum dry temperature inside building is around $29.2^{\circ} \mathrm{C}$, at 13.00 in the noon.

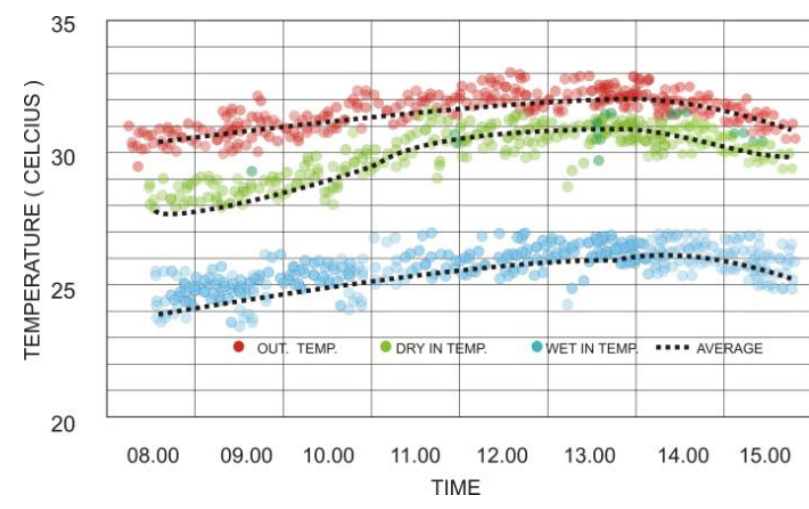

Figure 7. The temperature profile in the case of closed system

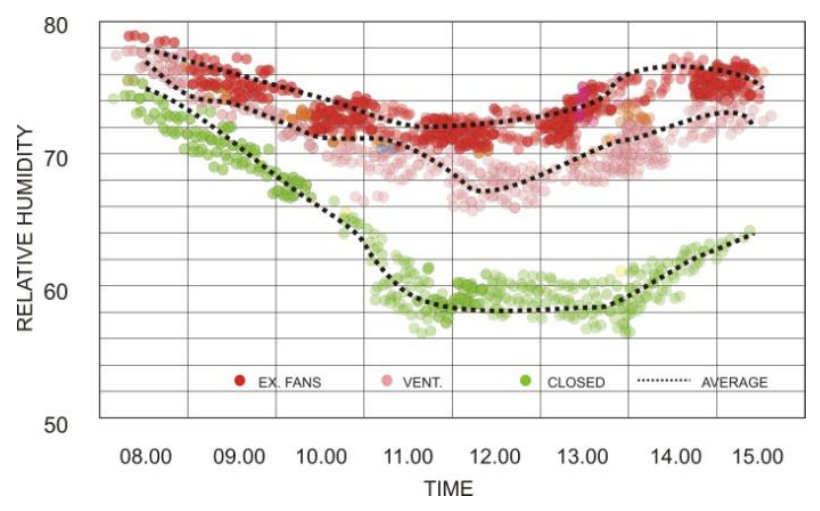

Figure 8 . The profile of Relative Humidity [RH]

Figure 7 shows the dry and wet bulb temperatures at inside the building and the temperature at outside in the case of no applying the ventilation or the circulating fan. The average maximum temperature at the inside of the building is around $31{ }^{\circ} \mathrm{C}$ (at 13.00 noon). Generally, in all time investigated, the temperatures in the building in this configuration are higher than those of applying the fan and ventilation (around 2 to $3{ }^{\circ} \mathrm{C}$ ).

Figure 8 shows the relative humidity $(\mathrm{RH})$ from the three configurations, obtained by plotting the dry and wet temperatures data into the Psychometric chart. For the building with the circulating fan, it is shown at 08.00 ; RH is around $79 \%$ in average, then decreasing to $77 \%$ at 10.00 . In 12.00 , it decreases to $72 \%$, then recovering to $78 \%$ in the afternoon. In the case of the building configurations with ventilation and no devices, the patterns are similar, but the amount is lower.

Figure 9 shows the air properties inside the building in the three proposed configurations and their comparison to those of the comfort zone (ASHRAE Standard) in the Psychometric chart. In the configuration of applying the fan, generally, the air properties tend to close to those of the comfort zone. This means that the application of the fan makes the condition of air inside the building relatively closer to comfort zone, than other configurations. In the case of no air conditioning devices, the air properties tend to be far from those of the comfort zone.

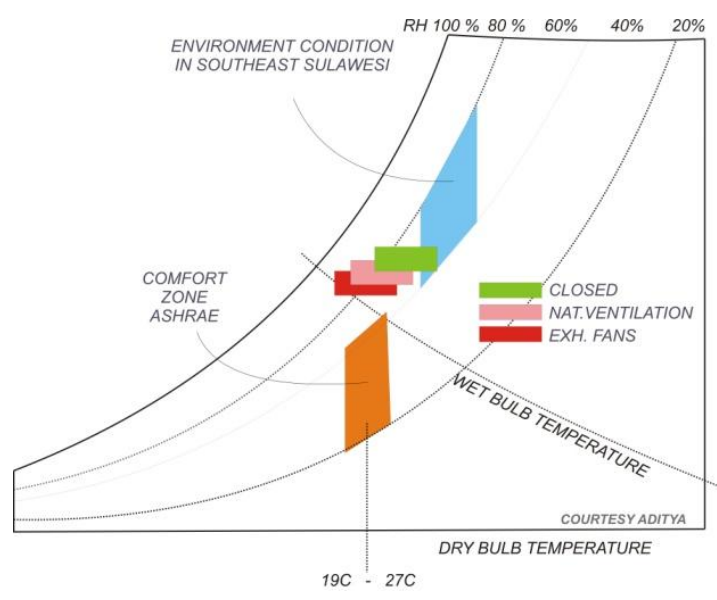

Figure 9. The condition of the temperature and the humidity in the three cases relative to that of the human comfort zone, represented in the Psychometric charts

Based on previous results, it is shown that the application of the exhaust fan and ventilation maintains the building temperature cooler than that of the building with no air driven devices. Indeed, 
the fan and ventilation in the building keep the relative humidity still at relatively higher than that of the closed building. These cause the air properties inside the building with the ventilating devices closer to those of the comfort zone, making the building more comfortable than that of the building with no devices.

\section{Conclusion}

This study has investigated the effect of the application of the fan and natural ventilation on the thermal comfort performance in a building. Following section is the conclusion that can be drawn.

The application of the fan and natural ventilation can decrease the temperature inside the building. The magnitude of the fan in the decrease of the temperature is higher than that of the natural ventilation. The application of the fan and natural ventilation can maintain the relative humidity at higher amount than that of the building without the air driven devices. Both conditions on the temperature and humidity in the building by the application of the fan and natural ventilation are closer to the air properties of the comfort zone in the psychometric chart, making more comfortable environment, than that of the building with no air driven devices.

\section{References}

ANSI/ASHRAE Standard 55. 2013, "Thermal Environmental Conditions for Human Occupancy"

ASHRAE-55. 2004, ASHRAE Standard- 55, American Society of Heating Refrigeration and Air-Conditioning, Engineers Inc., Atlanta.

Balaras, Constantinos A, Dascalaki E, Gaglia A. 2007. " HVAC and indoor thermal conditions in hospital operating buildings". Energy and Buildings. 39 (4): 454. doi:10.1016/j.enbuild.2006.09.004.

BPS Southeast Sulawesi, 2012, "Geography", Badan Pusat Statistik Sulawesi Tenggara

Brager GS, Dear RJ. 2000, "A standard for natural ventilation". ASHRAE Journal , 42 no10 O 2000, pp 21 - 28.

Candido C, Dear RJ, Lamberts R, Bittencourt L. 2010, "Air movement acceptability limits and thermal comfort in Brazil's hot humid climate zone". Building and Environment, 45(1), 222-229.

Carrier. 1974. "Carrier System Design Manual Part 1 Load Estimating and Psychrometircs". Australian Dept of housing and Construction, Canberra

Diamond R, Feustel H, Matson N. 2010. "EnergyEfficient Ventilation for Apartment Buildings, Rebuild America"

Feriadi, H, Wong NH. 2004," Thermal comfort for naturally ventilated houses in Indonesia". Energy and Buildings , 36 (2004) 614-626.

Heidari S. 2008, "A big problem - an easy solution". Proceedings of Conference: Air Conditioning and the Low Carbon Cooling Challenge . Cumberland Lodge, Windsor, UK, 27-29 July 2008: Network for Comfort and Energy Use in Buildings, London.

IPCC. 2014, “ Assessment Report "Climate Change 2014: Mitigation of Climate Change". IPCC Third Assessment Report Working Group III: Mitigation

Linden PF. 1999. "The Fluid Mechanics of Natural Ventilation". Annual Review of Fluid Mechanics. 31: 201238. Bibcode:1999AnRFM..31..201L.doi:10 .1146/annurev.fluid.31.1.201. edit

Liping W, Hien WN. 2007, “ Applying Natural Ventilation for Thermal Comfort in Residential Buildings in Singapore", Architectural Science Review, Volume 50.3, pp 224-233

NASA. 2014, Langley Research Center Atmospheric Science Data Center Surface meteorological and Solar Energy (SSE) web portal supported by the NASA LaRC POWER Project

National Renewable Energy Laboratory (NREL). 2001, "Cooling Your Home with Fans and Ventilation".

DOE/GO-102001-1278 FS228, June 2001,

Oropeza IP, Alberg P, Ostergaard. 2014. "Energy saving potential of utilizing natural ventilation under warm conditions - A case study of Mexico”. Applied Energy. 130, 1 October, 20-32 
Salas CMW, Castillo JA, Huelsz G. 2014. "Experimental study on natural ventilation of a building with a windward window and different windexchangers". Energy and Buildings, 84, December, Pages 458-465

UNEP [United Nation Environment Program]. 2014. "Sustainable Building and Climate Innitiative".

http://www.unep.org/sbci/AboutSBCI/Back ground.asp

Voss K, Schweiker M, Ubinas ER, 2013, Investigation of ceiling fans for improving summer thermal comfort, 2nd Central European Symposium on Building Physics Vienna, Austria, September 9-11

West J, Media D. 2013. "How to Use a Ceiling Fan to Reduce Heating Costs". http://homeguides.sfgate.com/use-ceilingfan-reduce-heating-costs-50085.html

World Meteorological Organizationn (WMO). 2008. "Guide to Meteorological Instruments and Methods Of Observation". WMO-8. Seventh edition. Chapter 2, Measurement of Temperature. 